\title{
SIMULTANEOUS SEPARATION AND PRECONCENTRATION OF TRACE AMOUNT OF COPPER, NICKEL, CADMIUM AND ZINC IONS ONTO MODIFIED AMBERLITE XAD-4 LOADED WITH 5-Br-PADAP
}

\author{
M.A. Taher ${ }^{*}$, A. Mostafavi, S.Z. Mohammadi Mobarake and D. Afzali \\ Department of Chemistry, Shahid Bahonar University, Kerman, Iran
}

(Received July 11, 2005; revised December 4, 2005)

\begin{abstract}
In this work, a simple, rapid, selective, sensitive and economical method has been developed for the simultaneous separation and preconcentration of trace amounts of copper, nickel, cadmium, and zinc in aqueous medium using XAD-4 resins that were modified with 2-(5-bromo-2pyridylazo)-5-diethylaminophenol (5-Br-PADAP) as an analytical reagent. The sorption is quantitative in the $\mathrm{pH}$ range 7.0-9.5, whereas quantitative desorption occurs instantaneously with $2 \mathrm{M} \mathrm{HCl}$ and selected trace elements have been determined using flame atomic absorption spectrometry. The linearity is maintained between $0.04-4.0 \mathrm{mg} \mathrm{L} \mathrm{L}^{-1}$ for copper, $0.1-4.0 \mathrm{mg} \mathrm{L}^{-1}$ for nickel, $0.02-1.3 \mathrm{mg} \mathrm{L}^{-1}$ for cadmium and $0.01-1.4 \mathrm{mg} \mathrm{L}^{-1}$ for zinc. The detection limits were $12 \mu \mathrm{g} \mathrm{L} \mathrm{L}^{-1}$ for $\mathrm{Cu}(\mathrm{II}), 30 \mu \mathrm{g} \mathrm{L}^{-1}$ for $\mathrm{Ni}(\mathrm{II}), 6 \mu \mathrm{g} \mathrm{L} \mathrm{L}^{-1}$ for $\mathrm{Cd}(\mathrm{II})$, and $4 \mu \mathrm{g} \mathrm{L}^{-1}$ for $\mathrm{Zn}$ (II) in the final solution. Various parameters such as the effect of $\mathrm{pH}$, flow rate, breakthrough volume and interference of a large number of anions and cations have been studied and the proposed method was used for determination of these metal ions in water and standard samples. In order to compare the proposed method, the actual water samples were analyzed by direct FAAS (using standard addition method). Determination of these metal ions in standard samples confirmed that the proposed method has good accuracy.
\end{abstract}

KEY WORDS: Simultaneous separation and preconcentration, Determination of $\mathrm{Cu}, \mathrm{Ni}, \mathrm{Cd}$, and $\mathrm{Zn}$, Amberlite XAD-4 resins modified with 2-(5-bromo-2-pyridylazo)-5-diethylaminophenol (5-BrPADAP), Analytical reagent

\section{INTRODUCTION}

Due to the industrial facilities, heavy metal contents in environmental samples increase unfavorably. So, it is very important and necessary to develop reliable, fast and sensitive methods for the determination of heavy metals in environmental and biological samples. Several techniques such as neutron activation analysis (NAA) [1], energy dispersive X-ray fluorescence (XRF) spectrometry [2, 3], inductively coupled plasma-atomic emission spectrometry (ICP-AES) [4, 5], atomic absorption spectrometry using either flame (FAAS) [6-8], or electrothermal atomization (ETAAS) [9-11], chromatography [12-16], electroanalytical techniques [17, 18], UV-Vis spectrophotometry [19-22], have been used for the multielement analysis in different matrices. Also, inductively coupled plasma-mass spectrometry (ICP-MS) can be used as a very popular technique for trace element determination. Most of these methods such as NAA, XRF and ICP-AES necessitate to use rather sophisticated and high cost operated instruments. High performance liquid chromatography (HPLC) having different techniques such as ion chromatography $[12,13]$, chelation ion chromatography [14, 15], and reversed phase liquid chromatography [16], were successfully used for multielement analysis but these techniques are time consuming and expensive. Also, the simultaneous determination of multielements by the use of traditional UV-Vis spectrophotometric techniques is difficult without any separation processes because of overlapping of absorption spectra.

Trace and toxic elements, such as cadmium, copper, nickel, and zinc in various samples have been important and great interest due to several hazardous effects that these elements could provide to humans. On the other hand, the direct determination of the trace metals in

*Corresponding author. E-mail: ma_taher@yahoo.com 
environmental waters by atomic absorption spectrometry (AAS) is very difficult due to the low levels of metal ions and also interfering influences of main components of the water samples. One way to solve this problem is separation and concentration the ion of interest in order to enhance the detection limit and selectivity and thereby improve the precision and accuracy of analytical results. Solid phase extraction is one of the several procedure techniques used for this purpose. The most common techniques available for this purpose are solvent extraction and solid-phase extraction using various adsorbents such as thiol cotton [23], activated carbon [24], green tea leaves [25], adsorption resins [26], cellulose [27], polythioether [28], microcrystalline naphthalene [29-31], Amberlite XAD-2 resin [32], octadecylsilica membrane disk [33], synthetic Zeolites [34], modified kaolinite [35] and analcime Zeolites [36]. Some of these adsorbents may be fairly effective for preconcentration of metal ions, but their methods of preparation are lengthy and involve rigid control of conditions. The solid-phase extraction process has received more acceptances due to a number of possible advantages including availability and easy recovery of the solid-phase, high preconcentration factors and easiness of separation and enrichment using continuous flow systems.

In this study, a simple, sensitive and rapid method for simultaneous separation and preconcentration of trace amounts of $\mathrm{Cu}(\mathrm{II}), \mathrm{Ni}(\mathrm{II}), \mathrm{Cd}(\mathrm{II})$, and $\mathrm{Zn}(\mathrm{II})$ ions has been proposed without any pretreatment processes.

\section{EXPERIMENTAL}

\section{Apparatus and reagents}

A Varian model SpectrAA 220 atomic absorption spectrometer was used for measuring $\mathrm{Cu}(\mathrm{II})$, $\mathrm{Ni}(\mathrm{II}), \mathrm{Cd}(\mathrm{II})$, and $\mathrm{Zn}(\mathrm{II})$ in air-acetylene flame. A Beckman $\mathrm{pH}$ meter was employed for $\mathrm{pH}$ measurements. A funnel-tipped glass tube $(60 \mathrm{x} 6 \mathrm{~mm})$ was used as a column for preconcentration. All glassware and columns were washed with a mixture of concentrated hydrochloric acid and concentrated nitric acid (1:1) before use. All reagents were of analytical reagent grade. The stock solutions of $\mathrm{Cu}(\mathrm{II}), \mathrm{Ni}(\mathrm{II})$, and $\mathrm{Cd}(\mathrm{II})$ were prepared by dissolving $1.000 \mathrm{~g}$ of copper, nickel and cadmium metal strip 99.99\% (Merck, Germany) in $20 \mathrm{~mL} \mathrm{1:1}$ nitric acid and diluted to 1 liter. The stock solution of $\mathrm{Zn}(\mathrm{II})$ was prepared by dissolving $1.000 \mathrm{~g}$ of zinc metal granules 99.99\% (Merck, Germany) in $40 \mathrm{~mL}$ 1:1 hydrochloric acid and diluted to 1 liter. The stock solutions were standardized by known methods given in the literature [37]. Working solutions were prepared by appropriate dilution of the stock solutions. A $0.5 \%$ solution of 2-(5-bromo-2-pyridylazo)-5-diethylaminophenol (5-Br-PADAP) in ethanol was prepared for complex formation with metal ions. Buffer solutions were prepared from $0.5 \mathrm{M}$ acetic acid and $0.5 \mathrm{M}$ sodium acetate for $\mathrm{pH} 3-6$, from $0.1 \mathrm{M}$ potassium dihydrogen phosphate and $0.1 \mathrm{M}$ disodium hydrogen phosphate for $\mathrm{pH}$ 6-8 and from 0.5 M ammonia and 0.5 M ammonium acetate for $\mathrm{pH}$ 8-11. Solutions of alkali metal salts (1\%) and various metal salts $(0.1 \%)$ were used in order to test the interference of anions and cations, respectively.

\section{Preparation of Amberlite XAD-4 column loaded with 5-Br-PADAP}

Amberlite XAD-4 was treated with an ethanol 96\%:1 M of hydrochloric acid:deionized water (2:1:1) solution overnight. The resin was rinsed with $10 \mathrm{~mL}$ of deionized water. Packing of the column must be done using ethanol as eluent since water makes resin beads float. The resin was saturated with the reagent by passing $5 \mathrm{~mL}$ of a $0.5 \%$ 5-Br-PADAP solution in ethanol at a flow rate of $1 \mathrm{~mL} \mathrm{~min}{ }^{-1}$. Afterwards it was washed with $10 \mathrm{~mL}$ of deionized water until reagent excess was eliminated from the resin. All experiments were done in a funnel-tipped glass tube $(60 \times 6 \mathrm{~mm})$ as a column for preconcentration. It was plugged with polypropylene fibers and 
then filled with the XAD-4 resin. Before sample loading the column must be preconditioned by passing a buffer solution. Then, the column could be used repeatedly for several times.

\section{General procedure}

An aliquot of copper, nickel, cadmium, and zinc (0.4-40.0 $\mu \mathrm{g}$ for copper, 1.0-40.0 $\mu \mathrm{g}$ for nickel, 0.2-13.0 $\mu \mathrm{g}$ for cadmium, and 0.1-14.0 $\mu \mathrm{g}$ for zinc) was taken in a $50 \mathrm{~mL}$ beaker and to it was added $3 \mathrm{~mL}$ buffer solution with $\mathrm{pH}$ 8.5. The total volume of the metal ion solution was made up to $30 \mathrm{~mL}$ with deionized water. Then, this solution was passed through the column at the flow rate of $3 \mathrm{~mL} \mathrm{~min}{ }^{-1}$. At the end, the column was eluted with $10 \mathrm{~mL}$ of deionized water. The adsorbed metal ions on the column were eluted with $10.0 \mathrm{~mL}$ of $2 \mathrm{M}$ hydrochloric acid solution at a flow rate of $1 \mathrm{~mL} \mathrm{~min}^{-1}$. The eluent was collected in a $10.0 \mathrm{~mL}$ volumetric flask. The final solution was aspirated directly into the flame of AAS against the blank prepared in the same manner without the addition of metal ions.

\section{RESULTS AND DISCUSION}

\section{Reaction conditions}

The reaction conditions were investigated with $10 \mu \mathrm{g}$ of $\mathrm{Cu}(\mathrm{II}), 15 \mu \mathrm{g}$ of $\mathrm{Ni}(\mathrm{II}), 4 \mu \mathrm{g}$ of $\mathrm{Cd}(\mathrm{II})$, and $\mathrm{Zn}(\mathrm{II})$, individually. Adsorption studies were carried out at different $\mathrm{pH}$, keeping the other variables constant. It was found that the zinc, nickel and cadmium were quantitatively adsorbed on modified resin in the $\mathrm{pH}$ range 7.0-9.5 and the copper complex was quantitatively adsorbed on resin in the $\mathrm{pH}$ range 4.0-9.5. The $\mathrm{pH}$ curves for all the metal ions are shown in Figure 1. In subsequent studies, the $\mathrm{pH}$ was maintained at approximately 8.5. Addition of 1-6 mL of buffer did not have any effect on the adsorption. Therefore, $3 \mathrm{~mL}$ of the ammonia-ammonium acetate buffer $\mathrm{pH} \sim 8.5$ was used in all subsequent experiments.

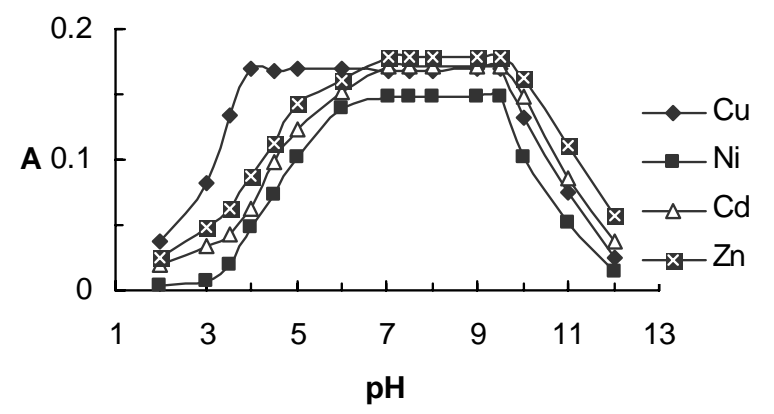

Figure 1. Effect of pH on adsorption of metal ions. (Conditions: Cu(II), $10.0 \mu \mathrm{g}$; Ni(II), 15 $\mu \mathrm{g}$; Cd(II) and $\mathrm{Zn}(\mathrm{II}) 4 \mu \mathrm{g}$ in final solution; buffer, $3 \mathrm{~mL}$; flow rate of sample, 3 $\mathrm{mL} \min ^{-1}$; final solution, $10.0 \mathrm{~mL}$ of $2 \mathrm{M} \mathrm{HCl}$ solution; flow rate of eluent, $1 \mathrm{~mL}$ $\min ^{-1}$; reference, reagent blank).

In order to test of sample volume on the recovery, different volumes (20 to $1700 \mathrm{~mL}$ ) of test solutions containing a fixed amount of the analyte (Cu(II), $10.0 \mu \mathrm{g}$; Ni(II), $15.0 \mu \mathrm{g}$; Cd(II) and $\mathrm{Zn}(\mathrm{II}) 4.0 \mu \mathrm{g}$ ) were enriched on the column. It was observed that absorbances were almost constant up to $1500,1000,1100$, and $1200 \mathrm{~mL}$ of the aqueous phase in the case of copper, nickel, cadmium, and zinc, respectively (preconcentration factor 150, 100, 110, and 120, 
respectively). However, for convenience, all the experiments were carried out with $30 \mathrm{~mL}$ of the aqueous phase.

A number of eluents were tested to desorb metal ions from the column. Organic solvents can be used as eluents, but they removed only 5-Br-PADAP reagent from the column. If acid solutions as eluent were used, the reagent was retained on the column and therefore, allowed using the column several times. Preliminary observations indicated that $2 \mathrm{M} \mathrm{HCl}$ desorbed these metal ions better than $2 \mathrm{M} \mathrm{HNO}_{3}$ and $\mathrm{H}_{2} \mathrm{SO}_{4}$. Hence, $10.0 \mathrm{~mL}$ of $2 \mathrm{M}$ hydrochloric acid was used in the present work.

The flow rate of the sample was varied from $0.5-10 \mathrm{~mL} \mathrm{~min}^{-1}$. It was found that a flow rate of 0.5-6 mL min ${ }^{-1}$ for $\mathrm{Cu}(\mathrm{II}), 0.5-4.5 \mathrm{~mL} \mathrm{~min}^{-1}$ for $\mathrm{Ni}(\mathrm{II}), 0.5-3.5 \mathrm{~mL} \mathrm{~min}^{-1}$ for Cd(II) and Zn(II)

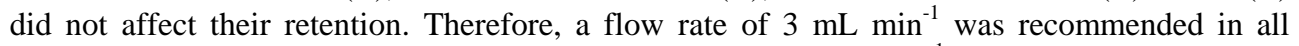
experiments. The flow rate of eluent was varied from $0.2-2 \mathrm{~mL} \mathrm{~min}^{-1}$. It was found that a flow rate of $0.2-1 \mathrm{~mL} \mathrm{~min}^{-1}$ for $\mathrm{Cu}(\mathrm{II}), 0.2-1.2 \mathrm{~mL} \mathrm{~min}^{-1}$ for $\mathrm{Ni}(\mathrm{II}), \mathrm{Cd}(\mathrm{II})$, and $\mathrm{Zn}$ (II) did not affect their desorbtion. Therefore, a flow rate of $1 \mathrm{~mL} \mathrm{~min}^{-1}$ was used in all experiments.

\section{Calibration and sensitivity}

Under the optimized conditions, calibration curves were constructed for the determination of copper, nickel, cadmium, and zinc according to the general procedure. Linearity in final solution was maintained between 0.04-4.0 $\mathrm{mg} \mathrm{L}^{-1}$ for copper, 0.1-4.0 $\mathrm{mg} \mathrm{L}^{-1}$ for nickel, 0.02-1.3 $\mathrm{mg} \mathrm{L}^{-1}$ for cadmium, and 0.01-1.4 $\mathrm{mg} \mathrm{L}^{-1}$ for zinc with correlation factors 0.9996, 0.9997, 0.9995, and 0.9994, respectively. Seven replicate determinations of mixture of $1.0 \mathrm{mg} \mathrm{L}^{-1}$ copper, $1.5 \mathrm{mg} \mathrm{L}^{-1}$ nickel, $0.4 \mathrm{mg} \mathrm{L}^{-1}$ cadmium and zinc in final solution give a mean absorbance of $0.1687,0.1483$, 0.1721 , and 0.1788 with relative standard deviation $\pm 1.2 \%, \pm 1.1 \%, \pm 1.3 \%$, and $\pm 1.4 \%$, respectively. The detection limits were $12 \mu \mathrm{g} \mathrm{L} \mathrm{L}^{-1}$ for $\mathrm{Cu}(\mathrm{II}), 30 \mu \mathrm{g} \mathrm{L}^{-1}$ for $\mathrm{Ni}(\mathrm{II}), 6 \mu \mathrm{g} \mathrm{L} \mathrm{L}^{-1}$ for $\mathrm{Cd}(\mathrm{II})$, and $4 \mu \mathrm{g} \mathrm{L}^{-1}$ for $\mathrm{Zn}(\mathrm{II})$ in the final solution. Sensitivities for $1 \%$ absorbance for $\mathrm{Cu}(\mathrm{II})$, $\mathrm{Ni}(\mathrm{II}), \mathrm{Cd}(\mathrm{II})$, and $\mathrm{Zn}(\mathrm{II})$ were 44.5 , 92.3, 8.2, and $3.8 \mu \mathrm{g} \mathrm{L} \mathrm{L}^{-1}$, respectively.

\section{Sorption capacity of resin for metal ions}

The sorption capacity of Amberlite XAD-4 with 5-Br-PADAP for metal ions was also evaluated. In this case the column containing $1 \mathrm{~g}$ of modified Amberlite XAD-4 was used and different volumes of $100 \mathrm{mg} \mathrm{L}^{-1}$ from copper, nickel, cadmium, and zinc solutions were passed through the column. Each time, effluent of the column was determined by using of flame atomic absorption spectroscopy until the effluent showed the presence of ions. The Amberlite XAD-4 has a sorption capacity of $0.166,0.088,0.154$, and $0.170 \mathrm{mg}$ per gram of XAD-4 resin for copper, nickel, cadmium, and zinc, respectively.

\section{Effect of different ions}

Various salts and metal ions were added individually to a solution containing $10 \mu \mathrm{g}$ of $\mathrm{Cu}(\mathrm{II}), 15$ $\mu \mathrm{g}$ of $\mathrm{Ni}(\mathrm{II}), 4 \mu \mathrm{g}$ of $\mathrm{Cd}(\mathrm{II})$ and $\mathrm{Zn}(\mathrm{II})$ ions, individually and the general procedure was applied. The tolerance limit was set as the concentration of the different ion required to cause $3 \%$ error. The results obtained are given in Table 1 . Among the cations and anions examined most could be tolerated up to milligram levels except EDTA which interferred seriously because of the higher stability constants of the metal-EDTA complexes than of the 5-Br-PADAP-metal complexes. Thus, the proposed method is selective and can be used for determination of these metals in environmental samples without any prior separation. 
Table 1. Effect of different salts and metal ions.

\begin{tabular}{|c|c|c|c|c|}
\hline \multirow{2}{*}{ Salt or metal ion } & \multicolumn{4}{|c|}{ Tolerance limit (mg) } \\
\hline & $\mathrm{Cu}$ & $\mathrm{Ni}$ & $\mathrm{Cd}$ & $\mathrm{Zn}$ \\
\hline $\mathrm{NH}_{4} \mathrm{Cl}$ & 100 & 120 & 120 & 200 \\
\hline $\mathrm{KNO}_{3}$, sodium acetate & 800 & 800 & 900 & 700 \\
\hline KI & 85 & 100 & 120 & 100 \\
\hline $\mathrm{K}_{2} \mathrm{SO}_{4}$ & 100 & 40 & 80 & 100 \\
\hline KSCN & 15 & 15 & 10 & 10 \\
\hline $\mathrm{Na}_{3} \mathrm{PO}_{4} \cdot 10 \mathrm{H}_{2} \mathrm{O}$ & 100 & 120 & 100 & 120 \\
\hline Sodium potassium tartrate & 18 & 20 & 15 & 50 \\
\hline $\mathrm{NaF}$ & 100 & 200 & 150 & 100 \\
\hline $\mathrm{Na}_{2} \mathrm{~S}_{2} \mathrm{O}_{3}$ & 10 & 15 & 10 & 5 \\
\hline Sodium oxalate & 30 & 20 & 15 & 12 \\
\hline $\mathrm{Na}_{2}$ EDTA & 0.2 & 0.05 & 0.06 & 0.06 \\
\hline $\mathrm{Mn}(\mathrm{II})$ from $\mathrm{Mn}\left(\mathrm{NO}_{3}\right)_{2} \cdot 4 \mathrm{H}_{2} \mathrm{O}$ & 3 & 2 & 0.5 & 0.5 \\
\hline $\mathrm{Ca}(\mathrm{II})$ from $\mathrm{Ca}\left(\mathrm{NO}_{3}\right)_{2} \cdot 3 \mathrm{H}_{2} \mathrm{O}$ & 50 & 50 & 40 & 40 \\
\hline $\mathrm{Mg}(\mathrm{II})$ from $\mathrm{Mg}\left(\mathrm{NO}_{3}\right)_{2} \cdot 6 \mathrm{H}_{2} \mathrm{O}$ & 100 & 80 & 40 & 20 \\
\hline $\mathrm{Co}(\mathrm{II})$ from $\mathrm{Co}\left(\mathrm{NO}_{3}\right)_{2} \cdot 3 \mathrm{H}_{2} \mathrm{O}$ & 3 & 1.5 & 1 & 1 \\
\hline $\mathrm{Mo}(\mathrm{VI})$ from $\mathrm{MoO}_{2} \mathrm{~F}_{2}$ & 3 & 2.5 & 1.5 & 1 \\
\hline $\mathrm{Bi}(\mathrm{III})$ from $\mathrm{Bi}\left(\mathrm{NO}_{3}\right)_{3} \cdot 5 \mathrm{H}_{2} \mathrm{O}$ & 5 & 3 & 1 & 2 \\
\hline $\mathrm{Pb}(\mathrm{II})$ from $\mathrm{Pb}\left(\mathrm{NO}_{3}\right)_{2}$ & 2 & 1.5 & 2 & 0.5 \\
\hline $\mathrm{Fe}(\mathrm{III})$ from $\mathrm{Fe}\left(\mathrm{NO}_{3}\right)_{3} \cdot 6 \mathrm{H}_{2} \mathrm{O}$ & 4 & 4 & 3 & 3 \\
\hline $\mathrm{Al}(\mathrm{III})$ from $\mathrm{Al}\left(\mathrm{NO}_{3}\right)_{3} \cdot 9 \mathrm{H}_{2} \mathrm{O}$ & 5 & 5 & 4 & 4 \\
\hline $\mathrm{Cr}(\mathrm{III})$ from $\mathrm{Cr}_{2}\left(\mathrm{SO}_{4}\right)_{3}$ & 4 & 3 & 3 & 2 \\
\hline $\mathrm{Hg}(\mathrm{II})$ from $\mathrm{HgCl}_{2}$ & 2 & 1 & 0.5 & 0.5 \\
\hline $\mathrm{Sb}(\mathrm{III})$ from $\mathrm{SbF}_{3}$ & 5 & 5 & 3 & 2 \\
\hline $\mathrm{Cu}(\mathrm{II})$ from $\mathrm{Cu}\left(\mathrm{NO}_{3}\right)_{2} \cdot 6 \mathrm{H}_{2} \mathrm{O}$ & - & 0.2 & 0.2 & 0.3 \\
\hline $\mathrm{Ni}(\mathrm{II})$ from $\mathrm{Ni}\left(\mathrm{NO}_{3}\right)_{2} \cdot 6 \mathrm{H}_{2} \mathrm{O}$ & 0.2 & - & 0.4 & 0.6 \\
\hline $\mathrm{Cd}(\mathrm{II})$ from $\mathrm{Cd}\left(\mathrm{NO}_{3}\right)_{2}$ & 0.2 & 0.3 & - & 0.2 \\
\hline $\mathrm{Zn}(\mathrm{II})$ from $\mathrm{Zn}\left(\mathrm{NO}_{3}\right)_{2} \cdot 3 \mathrm{H}_{2} \mathrm{O}$ & 0.2 & 0.2 & 0.3 & - \\
\hline
\end{tabular}

Conditions: $\mathrm{Cu}(\mathrm{II}), 10.0 \mu \mathrm{g}$; Ni(II), $15.0 \mu \mathrm{g}$; Cd(II) and Zn(II) $4.0 \mu \mathrm{g}$, individually in final solution; buffer, $3 \mathrm{~mL}$; flow rate of sample, $3 \mathrm{~mL} \mathrm{~min}^{-1}$; final solution, $10.0 \mathrm{~mL}$ of $2 \mathrm{M} \mathrm{HCl}$ solution; flow rate of eluent, $1 \mathrm{~mL} \mathrm{~min}^{-1}$; reference, reagent blank.

\section{Determination of metal ions in pepperbush and pond sediment}

The accuracy and applicability of the proposed method has been applied to the determination of these metal ions in National Institute for Environment Studies (NIES) No. 1 pepperbush and NIES No. 2 pond sediment. A 0.5 g sample was taken in a beaker and dissolved in concentrated nitric acid $(\sim 5 \mathrm{~mL})$ with heating. The solution was cooled, diluted and filtered. The filtrate was made to $100 \mathrm{~mL}$ with distilled water in a calibrated flask. An aliquot of the sample solution was taken individually and these metal ions were determined by the general procedure. The results are given in Table 2 and are in good agreement with the certified values.

Determination of $\mathrm{Cu}(\mathrm{II}), \mathrm{Ni}(\mathrm{II}), \mathrm{Cd}(\mathrm{II})$, and $\mathrm{Zn}(\mathrm{II})$ ions in water samples

The method has been employed for determination of these metal ions in spring and river water samples. A $200 \mathrm{~mL}$ water sample was adjusted to $\mathrm{pH} 1.5$ with nitric acid, filtered to remove suspended material and general procedure was applied. In order to compare the proposed method, the actual water samples were analyzed by direct FAAS (using standard addition method). The results were given in Table 3. 
Table 2. Determination of $\mathrm{Cu}, \mathrm{Ni}, \mathrm{Cd}$, and $\mathrm{Zn}$ ions in certified reference materials.

\begin{tabular}{|c|c|c|c|}
\hline Sample & Composition & Found $^{\mathrm{a}}\left(\mu \mathrm{g} \mathrm{g}^{-1}\right)$ & Recovery (\%) \\
\hline $\begin{array}{l}\text { NIES, No. } 1 \\
\text { Pepperbush }\end{array}$ & 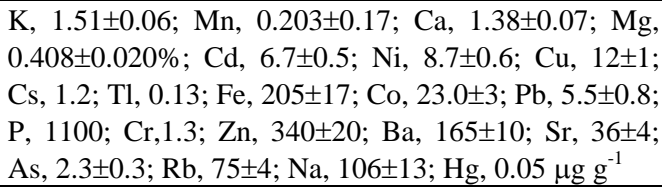 & $\begin{array}{l}\text { Cu: } 12.40 \pm 0.13 \\
\text { Ni: } 8.50 \pm 0.08 \\
\text { Cd: } 6.70 \pm 0.06 \\
\text { Zn: } 340.0 \pm 2.8\end{array}$ & $\begin{array}{l}103.3 \\
97.7 \\
100.0 \\
100.0\end{array}$ \\
\hline $\begin{array}{l}\text { NIES, No. } 2 \\
\text { Pond sediment }\end{array}$ & $\begin{array}{l}\mathrm{Al}, 10.6 \pm 0.5 ; \mathrm{Fe}, 6.53 \pm 0.35 ; \mathrm{Ca}, 0.81 \% \text {; } \mathrm{Zn}, 343 ; \mathrm{Cu} \\
\text { 210; Pb, 105; Cd, 0.82; Ni, 40; Cr, 75; Co, } 27 \mu \mathrm{g} \mathrm{g}^{-1}\end{array}$ & $\begin{array}{l}\text { Cu: } 210.0 \pm 1.1 \\
\text { Ni: } 40.20 \pm 0.12 \\
\text { Cd : < D.L. } \\
\text { Zn: } 343.0 \pm 2.4\end{array}$ & $\begin{array}{c}100.0 \\
100.0 \\
- \\
100.0\end{array}$ \\
\hline
\end{tabular}

${ }^{a}$ Average of five determinations, \pm standard deviation. ${ }^{b}$ Less than detection limit. NIES: National Institute of Environmental Studies reference materials. Conditions: Buffer, $3 \mathrm{~mL}$; flow rate of sample, $3 \mathrm{~mL} \mathrm{~min}{ }^{-1}$; final solution, $10.0 \mathrm{~mL}$ of $2 \mathrm{M} \mathrm{HCl}$ solution; flow rate of eluent, $1 \mathrm{~mL} \mathrm{~min}{ }^{-1}$; reference, reagent blank.

Table 3. Determination of $\mathrm{Cu}, \mathrm{Ni}, \mathrm{Cd}$, and $\mathrm{Zn}$ ions in water samples.

\begin{tabular}{|l|l|l|l|l|}
\hline Sample & $\begin{array}{l}\text { Element } \\
\text { determined }\end{array}$ & $\begin{array}{l}\text { Recommended } \\
\text { procedure }^{\mathrm{a}}\left(\mu \mathrm{g} \mathrm{L}^{-1}\right)\end{array}$ & $\begin{array}{l}\mathrm{FAAS}^{\mathrm{b}} \\
\left(\mu \mathrm{L} \mathrm{L}^{-1}\right)\end{array}$ & $\begin{array}{l}\text { Recovery } \\
(\%)\end{array}$ \\
\hline Spring water & $\mathrm{Cu}$ & $13.65 \pm 0.06$ & $13.58 \pm 0.05$ & 100.5 \\
& $\mathrm{Ni}$ & $18.08 \pm 0.04$ & $18.13 \pm 0.05$ & 99.7 \\
& $\mathrm{Cd}$ & $2.50 \pm 0.04$ & $2.53 \pm 0.03$ & 98.8 \\
& $\mathrm{Zn}$ & $56.60 \pm 0.46$ & $57.05 \pm 0.32$ & 99.2 \\
\hline River water of & $\mathrm{Cu}$ & $27.20 \pm 0.12$ & $27.36 \pm 0.11$ & 99.6 \\
Rayen in Kerman & $\mathrm{Ni}$ & $20.30 \pm 0.07$ & $20.26 \pm 0.05$ & 100.2 \\
& $\mathrm{Cd}$ & $4.47 \pm 0.06$ & $4.46 \pm 0.05$ & 100.2 \\
& $\mathrm{Zn}$ & $65.72 \pm 0.38$ & $66.19 \pm 0.44$ & 99.3 \\
\hline River water of & $\mathrm{Cu}$ & $30.64 \pm 0.14$ & $30.61 \pm 0.14$ & 100.1 \\
Kohpayeh in & $\mathrm{Ni}$ & $15.08 \pm 0.05$ & $15.12 \pm 0.04$ & 99.7 \\
Kerman & $\mathrm{Cd}$ & $3.41 \pm 0.03$ & $3.40 \pm 0.04$ & 100.3 \\
& $\mathrm{Zn}$ & $50.06 \pm 0.41$ & $50.10 \pm 0.32$ & 99.9 \\
\hline
\end{tabular}

${ }^{\mathrm{a}}$ Average of five determinations, \pm standard deviation. ${ }^{\mathrm{b}}$ Less than detection limit. NIES: National Institute of Environmental Studies reference materials. Conditions: Buffer, $3 \mathrm{~mL}$; flow rate of sample, $3 \mathrm{~mL} \mathrm{~min}{ }^{-1}$; final solution, $10.0 \mathrm{~mL}$ of $2 \mathrm{M} \mathrm{HCl}$ solution; flow rate of eluent, $1 \mathrm{~mL} \mathrm{~min}{ }^{-1}$; reference, reagent blank.

\section{CONCLUSION}

The aim of this study was to develop a suitable method for simultaneous separation and preconcentration of trace amounts of $\mathrm{Cu}(\mathrm{II}), \mathrm{Ni}(\mathrm{II}), \mathrm{Cd}(\mathrm{II})$, and $\mathrm{Zn}(\mathrm{II})$ ions in various samples with a recovery rate better than $97 \%$ of the expected concentration. The results of our study indicate that the procedure proposed, consisting of preconcentration of $\mathrm{Cu}(\mathrm{II}), \mathrm{Ni}(\mathrm{II}), \mathrm{Cd}(\mathrm{II})$, and $\mathrm{Zn}$ (II) followed by FAAS measurement in the aqueous phase, can accurately determine these metal ions in various aqueous samples. The main advantages of this procedure are: (i) the proposed method is sensitive and selective, (ii) it offers advantages like reliability and reproducibility in addition to its simplicity and suffers from less interference, (iii) the preparation of the extractor system is simple and fast, (iv) during desorption, the 5-Br-PADAP reagent remains in the column, which allows to use the column several times, and (v) good enrichment factors (100-150) can be achieved. 


\section{REFERENCES}

1. Zecca, L.; Tampellini, D.; Rizzio, E.; Giaveri G.; Gallorini, M. J. Radioanal Nucl Chem. 2001, 248, 129.

2. Lau, O.W.; Ho, S.Y. Anal. Chim. Acta 1993, 280, 269.

3. Eksperiandova, L.P.; Blank, A.B.; Makarovskaya, Y.N. X-Ray Spectrom. 2002, 31, 259.

4. Rao, K.S.; Balaji, T.; Rao, T.P.; Babu, Y.; Naidu, G.R.K. Spectrochim. Acta Part B 2002, 57, 1333.

5. Tepe, R.K.; Jacksier, T.; Barnes, M.R. J. Anal. Atomic Spec. 1998, 13, 989.

6. Tony, K.A.; Kartikeyan, S.; Vijayalakshmy, B.; Prasada, T.R.; Padmanabha, C.S.I. Analyst 1999, 124, 191.

7. Scaccia, S. Talanta 1999, 49, 467.

8. Chen, J.; Teo, K.C. Anal. Chim. Acta 2001, 434, 325.

9. Huang, Y.L.; Tsai, Y.F.; Lin, T.H. Anal. Sci. 1999, 15, 79.

10. Lin, P.-H.; Danadurai, K.S.K.; Huang, S.-D. J. Anal. Atomic Spec. 2001, 16, 409.

11. Zendelovska, D.; Pavlovska, G.; Cundeva, K. Stafilov, T. Talanta 2001, 54, 139.

12. Cardellicchio, N.; Cavalli, S.; Ragone, P.; Riviello, J.M. J. Chromatogr. A 1999, 847, 251.

13. Santoyo, E.; Santoyo-Gutierrez, S.; Verma, S.P. J. Chromatogr. A 2000, 884, 229.

14. Ding, X.; Mou, S.; Liu, K.; Yan, Y. J. Chromatogr. A 2000, 883, 127.

15. Lu, H.; Yin, X.; Mou, S.; Riviello, J.M. J. Liq. Chromatogr. Rel. Technol. 2000, 23, 2033.

16. Li, Z.; Yang, G.; Wang, B.; Jiang, C.; Yin, J. J. Chromatogr. A 2002, 971, 243.

17. Reyes-Salas, E.O.; Dosal-Gomez, M.A.; Barcelo-Quintal, M.H.; Manzanilla-Cano, J.A. Anal. Lett. 2002, 35, 123.

18. Opido, J. Mikrochim. Acta 2001, 137, 157.

19. Pancras, J.P.; Puri, B.K. Anal. Sci. 1999, 15, 575.

20. Khayamian, T.; Ensafi, A.A.; Hemmateenejad, B. Talanta 1999, 49, 587.

21. Safavi, A.; Abdollahi, H. Anal. Lett. 2001, 34, 2817.

22. Ghasemi, J.; Niazi, A. Microchem. J. 2001, 68, 1.

23. Yu, M.Q.; Liu, G.Q.; Jin, Q. Talanta 1983, 30, 265.

24. Vanderborght, B.M.; Vangrieken, R.E. Anal. Chem. 1977, 40, 311.

25. Kimura, K.; Yamushita, H.; Kondda, J. Bunseki Kagaku 1986, 35, 400.

26. Soylak, M.; Elci, L. Int. J. Environ. Anal. Chem. 1997, 66, 51.

27. Burba, P.; Willmer, P.G. Talanta 1983, 30, 381.

28. Khan, A.S.; Chow, A. Talanta 1986, 33, 182.

29. Taher, M.A. Anal. Sci. 2001, 17, 969.

30. Taher, M.A. Talanta 2000, 52, 181.

31. Taher, M.A.; Puri, B.K. Talanta 1999, 48, 355.

32. Ferreria , S.L.C.; Brito, C.F.D.; Danats, A.F. Talanta 1999, 48, 1137.

33. Bagheri, M.; Mashhadizadeh, M.H.; Razee, S, Talanta 2003, 60, 839.

34. Pena, Y.P.; Lopez, W.; Burguera, J.L.; Burguera, M.; Gallignani, M.; Brunetto, R.; Carrero, P.; Rondon, C.; Imbert, R. Anal. Chim. Acta 2000, 403, 249.

35. Afzali, D.; Taher, M.A.; Mostafavi, A.; Mohammadi Mobarakeh, S.Z. Talanta 2005, 65, 476.

36. Taher, M.A.; Mostafavi, A.; Afzali, D.; Rezaei Pour, E. Bull. Korean Chem. Soc. 2004, 25, 1125.

37. Mendham, J.; Denney, R.C.; Barnes, J.D.; Tomas, M. Vogel's Text Book of Quantitative Chemical Analysis, 6th ed., Pearson Education Limited: England; 2000; pp. 383, 384, 393, 555. 